\title{
Semiotics as a postmodern recovery of the cultural unconscious
}

\author{
John Deely \\ University of St. Thomas, \\ 3800 Montrose Boulevard, Houston, Texas, U.S.A. \\ e-mail: deelyj@stthom.edu
}

\begin{abstract}
This essay explores the terminology of semiotics with an eye to the historical layers of human experience and understanding that have gone into making the doctrine of signs possible as a contemporary intellectual movement. Using an essentially Heideggerian view of language as a heuristic hypothesis, the name semiotics is examined in light of the realization that only with Augustine's Latin signum was the possibility of a general doctrine of signs introduced, and that first among the later Latins was the idea of sign as a general mode of being specifically verifiable both in nature and in culture in establishing the texture of human experience vindicated according to an explanation of how such a general mode of being is possible. The contemporary resumption through Charles Peirce of the Latin line of vindication completed especially by Poinsot is explored along these same lines in terms of considerations of why the term semiotics has emerged as, so to speak, the logically proper name of the global interest in signs.
\end{abstract}

As Galileo and Descartes experienced their situation, the new learning was to be a turning away from authority based on the interpretation of linguistic texts to establish a new authority based on experimental results expressed in mathematical reasoning. At the beginning the two tried, as it were, to walk arm in arm, to stand shoulder to shoulder in a war to delegitimize the mentality and methods bizarrely canonized centuries after the fiasco in the person of "saint" Robert Cardinal Bellarmine, Rome's own Torquemada.

But soon enough, in spite of themselves, the followers of these two found themselves parting ways, the line of Galileans leading to New- 
ton, Einstein, and Mission Control in Houston placing men on the moon and ships bound for the far stars, the line of Cartesians leading to Hume and Kant and a reluctant conviction that the universe of reality prejacent to and independent of the human mind is a universe forever unknowable. Modern philosophy, in short, came to play Mr. Hyde to the Dr. Jekyl of modern science, which remained convinced in its practitioners that reality was just what was being revealed and brought more and more under the arts of human practical knowledge, exactly as the medieval Aquinas had expressed it: that the speculative understanding of the being of nature becomes by extension practical when human beings find the means to turn that understanding of nature to use.

Locke, of course, had tried to intervene in the Cartesian development to give credit and credence to the role our senses play in feeding the growth of human understanding, but his intervention was without avail for deflecting the main trajectory of the mainstream modern development in philosophy as a kind of semiotic lapse. For, by accepting Descartes' reduction of objects to representations made by the mind, he foreclosed the only avenue by which the understanding moves back and forth in its grasp of objects between the realms of nature and culture, considering the last, as Vico said, as our own construction, even as the former comes somehow from the hand of God, as the moderns mainly assumed.

To be sure the Latins had only themselves to blame for being consigned in turn to the flames of modernity. A decent interval had to pass before the outrages of the Latin authorities could fade into the oblivion of consciousness of the living generations, and it was probably inevitable that, along with the healing of the wounds of that memory, the speculative achievements of the Latins in illuminating the nature of the workings of properly human understanding and the semiotic structure of the experience upon which it depends and feeds, as we now realize looking back, should also for a time suffer oblivion. But it is time to separate the chaff from the wheat, and to go back over the fields of Latin philosophy and civilization to see what might be retained or rehabilitated in the area of the philosophy of being, still, after all, the most ample of the interpretive horizons ever achieved within philosophy, and arguably the one most proper to the nature of understanding itself as the linguistic dimension of the human modeling system whereby alone a relative freedom from or transcendence 
over the perceptual horizon of sensation is achieved within our experience of objects not all of which reduce to our experience of them.

The clearest beginnings of such a recovery as far as concerns semiotics, surely, came through the work of Umberto Eco and his marvelous team of students and colleagues at the University of Bologna, who were able to report that, despite our fondness in philosophy for tracing Greek origins of main concepts, in the case of the sign, the key concept of a general mode of being superior to the division between nature and culture was owing to the Greeks not at all but to one ignorant of Greek, Augustine of Hippo. After Augustine, there will be both natural and cultural signs; but before Augustine, the Greeks had thought of the sign mainly, almost exclusively, in natural terms. The

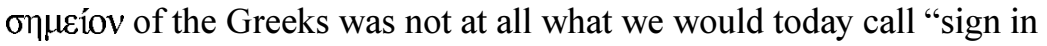
general" but rather "natural sign in particular". The notion of sign in general was, precisely, signum, Augustine's Latin term proposed just as the $4^{\text {th }}$ century closed to express the idea that the universe of human experience is perfused with signs, not only through our contact with the natural being of our physical surroundings in the signs of health and weather, but also through our contact with our conspecifics in discourse and trade, even in our contact with the divine through sacrament and scripture.

There was no turning back. The Latin Age was born in the perspective of the sign as the pervasive instrument of understanding. It would take almost twelve centuries for the consequences of that fact to be worked through to their speculative ground in the Treatise of Signs of John Poinsot, contemporary of Galileo and Descartes, to be sure, but a man as decisively of the Latin past as Galileo and Descartes were men of the modern future. For human beings are animals first of all, and animals first of all experience the universe of nature not as things but as objects to be sought and avoided or ignored. Animals make use of signs without knowing that there are signs, let alone without realizing that signs are in the objective world of experience an instrument as universal as is motion in the world of physical being. ${ }^{1}$

In their absorption in the world of objects, the sign appeared to the Latins, even to Augustine in making his general proposal, not in its pure and proper being as a triadic relation (indifferent, like all relations, to the surrounding circumstances which make it physically real

The most interesting formulation of this point by far among contemporary writers is to be found in Jacques Maritain 1937-1938: 1; 1938: 299; 1956: 59; 1957: 86. Comprehensive discussion in Deely 1986a. 
as well as objectively so, or only objective), but rather in its sensible manifestation as a connection between objects experienced whereby the one, on being perceived, manifests also another besides itself, perhaps even one absent from the immediate perceptual surroundings. That objects in order to be experienced at all presuppose signs already at work in the activity of understanding never occurred to the Latins, though that was a clear consequence (clear, that is, after the manner of all consequences, which is to say, once it is further realized) of the realization that the being proper to signs is not at all that of something sensible as such but that of relation as irreducible to whatever aspects of subjectivity the relation happens to depend upon for its existence in these or those concrete circumstances.

The privilege of the Latins was first to propose and then to vindicate the general notion of signs. After that came modernity, a new way of approaching the understanding of objects as such still prior to the further realization that objects presuppose signs, and indeed, developed in a manner contrary to what such a realization would require. ${ }^{2}$ Finally came the dawn of postmodernity, the recovery of signum in the work of the first American philosopher worthy to be named in the company of Aristotle and Aquinas, Charles Sanders "Santiago" Peirce. He was among the last of the moderns, to be sure; but, more importantly, he was the first of the postmoderns, because he was the first after Descartes (with the partial exception of Hegel) to show and to thematize the inclusion within the world of objects something also of the physical being of nature in its own right, just as it is in its prejacency to and insouciant independence of systems of human belief and speculation.

The Latins had uncovered and identified the being proper to signs as the base of our experience of objects. But action follows upon being. The next step perforce would be to thematize the action of signs precisely in order to understand in detail what the being proper to sign entails. And this is precisely the step Peirce took after first learning most, though not all, of what the Latins had discovered of the sign in its proper being. He even gave to this action a name, semiosis, as the subject matter whose study results in a distinctive form of philosophical and even scientific knowledge, semiotics, just as biology is a body of knowledge that develops out of the study of living things, and geology out of the study of the earth. The Latins too had demonstrated the

2 See the details of the case as presented in Deely 1994a, along with the comments of Santaella-Braga 1994. 
necessity of three terms involved in every sign, but their living tradition ended before any had thought to name that third term. This too fell to Peirce, who called it the interpretant, and who further saw without quite ever succeeding to explain that the interpretant need not involve finite consciousness.

The bare proposal for semiotics that Locke had contradicted his own Essay by making, of course, came near the beginning of modern thought; but it had no influence on the modern development. Nor did it embody any awareness of the Latin past in this matter, save perhaps in the bare echo in the English expression "doctrine of signs", which Locke used to translate his nouveau Greek term (malformed)

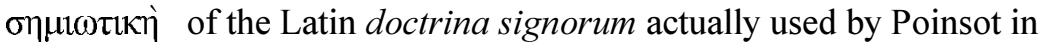
explaining the content and plan of his Treatise on Signs. Had the proposal been influential in its time, we would not now be speaking of postmodernity, for the mainstream modern development of philosophy (as distinct from science ${ }^{3}$ ) would have been aborted thereby. But the proposal was not influential; and Mr. Hyde had many years to live and to grow into the monstrosity of idealism, the doctrine that whatever the mind knows in whatever the mind knows of it the mind itself creates, a doctrine which the late modern philosopher Jacques Maritain, in exasperation, at last proposed ${ }^{4}$ should be denied the very name of philosophy in favor of something like "ideosophy" instead. ${ }^{5}$

As early as Locke's proposal for semiotics, the achievement of the Latin Age in first proposing and finally explaining the being proper to sign as a general mode of being had already crossed the social line separating contemporary concerns from the cultural unconscious, that limbo for the achievements of previous generations of human animals which have slipped outside the focus of the consciousness of a yet living generation of human animals. So let me try to show how, in refocusing on the sign, postmodern thought has as part of its destiny to recover the whole of the Latin Age unified in an unexpected way by the theme of the sign, a theme which, we will see, reprises all the standard issues covered in the "standard presentation" of medieval

\footnotetext{
3 I have published preliminary statements on the distinction between philosophy as doctrina and modern science as scientia in Deely 1978, 1982a, 1986b; but the full justification of this distinction as a thesis concerning the history of philosophy as a whole over its development before, during, and after the modern period is to be found in Deely 2000a.

4 Maritain 1966.

5 But, except for the astonishing writings on this point of Peter Redpath, Maritain's suggestion so far has fallen on deaf ears.
} 
philosophy from Augustine to Ockham heretofore, but reprises them as subordinate themes to that of the sign, which is the one theme which unifies the age as an organic whole, and so goes beyond the "standard coverage" by requiring us to take account of that series of thinkers after Ockham which link the Treatise on Signs of Poinsot that culminates the semiotic line of Latin development as well to that series of thinkers before Ockham that begins with Augustine.

\section{The language of semiotics}

The Latin contribution to our European heritage of semiotics is massive $\mathrm{C}$ original, foundational, pervasive, yet at least temporarily, inconscient in the greater part of those intrigued with signs. The situation is hardly static, but it remains true that as we enter the last months of the second millennium of the common era, the Latin contribution to semiotics exists mainly as a current or layer within the cultural unconscious, yet one which little by little has begun to be brought into the light of conscious awareness beginning especially, as I have said, with the work of Umberto Eco for the world at large; but also, within the Hispanic world, by the publications of Mauricio Beuchot. The contemporary development of semiotics, we are beginning to see, owes far more to the Latin Age than it does either to modern or even to ancient times, which is not at all to deny the singular importance of the ancient Greek medical heritage so forcefully brought out first by Sebeok. ${ }^{6}$ Nevertheless, the Latin Age has in our cultural heritage in the matter of the sign a historical weight (here, I can no more than suggest) that perhaps manifests its inertia in the improbable reversal of fortunes of the two terms under which contemporary study of signs has organized itself, namely, "semiology" (first and everywhere in the first six or seven decades of the $20^{\text {th }}$ century), then "semiotics" (here and there in the $60 \mathrm{~s}$, and now become dominant over the waning band of those who, more and more wistfully, label themselves "semiologists" $)$. There is after all a weight of language, an inconscient capacity of words subtly to shade the tint of even the most present experience with the perspective and understanding of generations past, as if

See esp. Sebeok 1975, 1984, 1984c, and 1996.

See the survey of usage in Sebeok 1971; then further "Rectificando los terminos 'semiótica' y 'semiología", in Deely 1996: 300-317; and "Ferdinand de Saussure and Semiotics" in Tasca 1995: 75-85. 
the ghosts of those generations were whispering memories into the mind's ear as each new generation learns to speak.

Nor are my dates of demarcation, the end of the $4^{\text {th }}$ and the beginning of the $17^{\text {th }}$ century, arbitrary. For if we look at the Latin history in philosophy in the light of sign as a theme, we discover something astonishing: instead of a chaotic age going off in many directions, one only gradually achieving a center of gravity in the so-called "high medieval" period and afterward dissolving into nominalism and the exuberance of the Renaissance recovery of Greek classics, we find a distinctive age of philosophy organically unified from beginning to end above all by its first speculative initiative made in philosophy without precedent or anticipation in the world of ancient Greek philosophy. The sign, it turns out, was not only the original Latin initiative in philosophy, as Eco discovered, but, what seems never to have occurred to Eco's circle, the sign provides the theme that shows a true unity of that age in moving from the simple positing of the fundamental notion to its complex justification as no flatus vocis but rather the nexus of human experience as transcending nature in the direction of mind and back again from mind in the direction of nature.

In speaking thus we take up a theme from a German philosopher who dominated the $20^{\text {th }}$ century with his cryptic pronouncement that "Language is the house of Being". 8 For "language" here did not signify at all what, say, the everyday American or Italian refers to by the vocable "language". On the contrary, Heidegger meant something much more profound, what our American paterfamilias Thomas Sebeok - no everyday American, he, but rather, as I have explained elsewhere, ${ }^{9}$ and as many in this room independently and easily understand, a putative Martian and (what comes to the same), like Vilmos Voigt, a Hungarian - explains rather ${ }^{10}$ as the product of our Innenwelt or "modeling system", that species-specifically human capacity which results in an Umwelt, an objective world, an arrangement of objects classified as desirable, contemptible, or beneath notice $(+,-$, 0 ) insofar as that typically animal arrangement of experience is further permeated and transformed by the human awareness of an interpretive horizon for these objects as specifically consisting of more than their relation to the one perceiving them, and thus carrying a history which imports into the individual consciousness, for the most part unknow-

Heidegger 1947.

See Tasca 1995.

10 Sebeok 1984b and elsewhere. 
ingly but nonetheless in fact, a structure of awareness and experience which links the individual with the understanding of the world worked out and adhered to by forebears long dead whose codifications of understanding are embodied in the words we speak, those linguistic vessels which, all but entirely, preceded our individual births and will continue at play in linguistic communication long after we have died.

So the "being" which language houses is above all a historical reality, the preservation in human community of the affective and cognitive links which have their roots in times long past but which define through their presence in the psychology of living individuals the contours of what we call a natural language community, with all the vagueness and inevitable overlappings that result in that notion as a consequence of the fact that the human modeling system, alone among the animal modeling systems on this planet, is not restricted in its communicative elements and terms to sign-vehicles objectively accessible as such to sense perception.

It is from this point d'appui that I want to address, with an eye to our Latin past, the present development and immediate future of semiotics. For if language is, to speak in the accents properly Heidegger's own, a seinsgeschichtliches Wesen, an essence freighted with being, then it is surely there, indeed, in the vocable itself "semiotics"(something that Heidegger himself never considered, even as he was typically ignorant of almost every one of the late Latin thinkers who were key to the semiotic denouement of their age in philosophy), that our heritage lies at once concealed and manifestly present in its permeation of and influence over thinkers wherever the semiotic community has taken root in our nascent contemporary "global culture". Even moreso is this the case with the simple vocable "sign". So let us reflect on the Latin dimension of our heritage as it is carried within two simple English words: first "sign", and then "semiotics". What, even inconsciently, do these two simple expressions import into our present experience of the world from the predominantly Latin phase of the European development?

\section{From Latin signum to English sign}

The ontological weight of Latin history at play in the shaping of our contemporary use of "sign" is conveyed through a derivation directly and immediately Latin: signum. There is a conjecture that this Latin 
term carries over a Sanskrit sense of "to cling to or adhere", which is probable, but not probable enough to pursue for present purposes. For, so far as it is a question of the concept and destiny of sign that furnishes the foundations for what we have come to call semiotics, namely, the body of living knowledge developed out of the thematic observation and analysis of the action unique and proper to signs (both as such and in their various kinds), we are dealing with a coinage that as a matter of fact does not go beyond a rather late stage of the Latin language itself, it being a posit, as has been discovered, put into play just three years before the end of the fourth century of the Christian or "common" (if you prefer) era.

Well, by coincidence, this was the very time when the move of the capital of Roman Empire from Rome to the Byzantine region had just been consolidated. This was the time when the peoples who would form Europe were adopting the original Latin tongue of the old empire, while the rulers themselves were abandoning Latin in favor of the Greek language. This was the time, in short, when we witness in hindsight the astonishing split of a single political entity, the Roman Empire, into two halves soon to share virtually no common linguistic tie.

It is common wisdom that the term "semiotics" comes from the

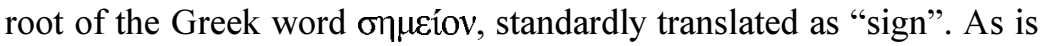
all too often true of common wisdom, so in this case it forms a dangerous alliance with ignorance by concealing more than it reveals without any overt hint of what is hidden. The alliance is dangerous in this case because what the common wisdom conceals is of far greater import for any deep understanding of a European heritage in the matter of the study of signs than what it would lead the first-time comer to that study to believe. For the truth is, the astonishing truth, with which semiotic reflection needs most to begin, is that there is no general concept of sign to be found in Greek philosophy, and the term stan-

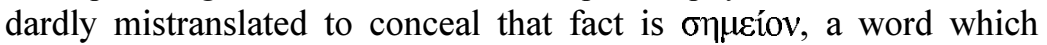
means, in Greek, not at all "sign" in any general sense but only very specific forms of sign, particularly ones associated with divination, both in the invidious sense of prophetic and religious divination and in the more positive scientific sense of prognostications in matters of medicine and meteorology. ${ }^{11} \Sigma \eta \mu \varepsilon i ́$, in other words, are from outside the human realm, are from nature, either in the manifestations of the gods or in the manifestations of the physical surroundings. Within the human realm are found not signs but symbols $(\sigma 0 ́ \mu \beta 0 \lambda \alpha)$ and, what is

11 Manetti 1993. 
after all but a subclass of symbols, names (ovo $\mu \alpha \tau \alpha)$, the elements in general of linguistic communication.

All this will change after Augustine (354-430AD). Too busy in his youth for one set of reasons to learn the Greek language in use all around him, too busy in later years for another set of reasons to learn the Greek language visibly losing ground in the Western regions of Roman empire but yet dominating the realm of theological and religious discussion, and, in any event, disinclined by temperament to study Greek in any season, ${ }^{12}$ Augustine it was who, in an ignorant bliss, began to speak of sign in general, sign in the sense of a general notion to which cultural as well as natural phenomena alike relate as instances or "species". Not knowing Greek, he was ignorant of the originality of his notion. That he was proposing a speculative novelty never crossed his mind, and, his principal readers being similarly ignorant, the fact is not known to have occurred to any one in his large and growing audience. What was obvious to the Latins was the intuitive clarity of the notion and its organizing power. Look around you. What do you see? Nothing or almost nothing at all that does not further suggest something besides itself, something that almost normally is not itself part of the physical surroundings immediately given when you "look around". There is a tombstone, my childhood friend's grave; there is a tree, the one planted for the occasion of the burial; there is a pot of flowers now dead, placed here a month ago to honor the memory of this friend. And so on.

Nothing at all is all that it appears. Everything is surrounded by the mists of significations which carry the mind in many directions, all according to knowledge, interest, and level of awareness brought to bear at any given moment when we happen to "take a look around". Of course all these perceptions involve signs, the gravestone no less than the cloud. And the fact that the one comes from human artifice and the other from nature makes no difference to the fact that both alike signify, that both alike, in Augustine's words, "praeter species quas ingerit sensibus aliquid aliud facit in cognitionem venire" ("over and above the sense impressions, make something besides themselves come into awareness").

So little were Augustine and the Latins after him aware of the novelty of their general notion of sign, indeed, that the novelty would appear never to have come to light before researchers of our own time turned the tools and light of scholarship to uncovering the historical

12 Augustine 397: i, 14. 
origins of semiotics. To my knowledge at least, as I have several times indicated, it was the team of researchers who have worked the fields of ancient thought from a semiotic point of view under the guidance and tutelage of the celebrated Italian scholar and Bologna professor, our friend Umberto Eco, who first brought to light ${ }^{13}$ and subsequently established more fully ${ }^{14}$ Augustine's incognizant originality in this particular. ${ }^{15}$ Whatever be or not be the Sanskrit overtones, the English word "sign" comes directly and immediately from the root of the Latin term signum, and this term with the familiar general sense it has for semiotics, of providing a subject matter that merits investigation into natural and cultural phenomena alike, was a novelty in the maturity of Augustine.

So there is the earliest and second most definitive ${ }^{16}$ landmark in the Latin heritage of postmodern semiotics: the very notion of sign in the general sense was introduced at the dawn of the $5^{\text {th }}$ century AD to draw attention to and mark the fact that all our objects of sense perception are experienced within a web of relations that much later thinkers - Thomas Sebeok in particular, developing a suggestion in the work of Jakob von Uexküll - aptly designate a semiotic web. The very word "sign" is itself a sign self-reflexively of the not only of the Latin but indeed of the European heritage in this area, the very con-

13 See esp. Eco, Lambertini, Marmo, and Tabarroni 1986; and the the editorial note on the provenance of this text, ibid. p. xix.

14 Manetti 1993.

15 The discovery entered our semiotic literature of today as an anomaly, a curious fact that, like Albert the Great's fossils in the 1260s, puzzled the mind without suggesting any grand hypotheses. Ironically, when an abduction was finally made and formally presented full-scale in the work of Manetti just cited, the guess missed and, for want of a familiarity with the key texts of later Latin times, as we will have occasion to mention, proffered the wild hypothesis that it was the Latins themselves, and not the late modern structuralists and deconstructionists heir to Saussure, who began the development that culminated in the semiological thesis that there are only conventional signs. See the essays referred to in note 3, p. 2, above; but especially Chapter 16 in the Four Ages of Understanding. Nonetheless, the asymmetry of ancient Greek and modern national language philosophy on this point is worthy of note: as the ancients recognized only natural signs, so the moderns came in the end to recognize only conventional signs. The Latins, by contrast, like Peircean postmoderns, are distinguished by the theoretical means of recognizing both.

16 The most definitive landmark, of course, would by rights be the theoretical demonstration that the general notion of sign was a warranted notion. But "rights" in these matters are, from the standpoint of popular culture, matters of some amusement, when they are recognized at all; were it otherwise, Poinsot would have been from the start, and not merely as a matter of future tenancy, far better known among semioticians than Augustine. 
crete fact that "Europe" was the gradual creation of the heirs and interlopers to the original Western lands of the Roman Empire who took over also its original language. This mélanges of peoples inherited and transformed the original language of that Empire through an indigenous philosophical development that began roughly in the $4^{\text {th }}$ century and continued thereafter until the $17^{\text {th }}$ century, the time of the decisive break of modernity from the Latin Age both in the establishment of science in the modern sense (as an intellectual enterprise distinct no less from philosophy than from theology and religious thought) and in the establishment of the developing national languages in place of Latin as the principal vehicle henceforward for the sustenance of European intellectual culture.

For since semiotics is the body of knowledge that develops through the study of the action of signs, as biology is the systematic knowledge that is developed from the study of behavior of living things, etc., semiotics may be said to have actually arisen only at that moment when the general notion of sign as a unified object of possible investigation was introduced. The mere fact that, prior to such a conception, there were signs at work throughout the living world (and, both beyond and before that, perhaps, in the wide world of physical nature itself, as Peirce first proposed ${ }^{17}$ and as has more recently been analyzed under the rubric of "physiosemiosis" "18), does not mean that there was semiotics in the universe prior to the Latin Age - except, of course, as a possibility in the sense of having a place "marked out in advance", as Saussure so well put it. ${ }^{19}$ Semiosis, Peirce's name for the action of signs taken from - or, rather, forged on the basis of remarks in the Epicurean papyrus written by Philodemus in the last century preceding the common era, ${ }^{20}$ precedes semiotics, just as living things precede biology and rocks precede geology. But biology as a science presupposes that the world of living things be conceived as a thematically unified subject of possible systematic inquiry. Similarly, a doctrine of signs presupposes that the action of signs be conceived as a thematically unified subject matter of possible investigations. And

\footnotetext{
17 His "grand vision", I would call it (Deely 1989).

18 A term coined in Deely 1990 and developed in a series of essays after that, most recently 1996 and 1997.

19 Saussure 1916: 16.

20 Philodemus i. 54-40BC. See Fisch 1978: 40-41 for discussion of Peirce's derivation and coinage.
} 
the first to give us a notion of sign which accomplishes this presupposed feat was Augustine.

Of course there were investigations of various kinds based on the action of signs long before Augustine. Indeed, we now realize that every investigation is based on the action of signs, every investigation has a semiotic component or dimension that can be brought out and highlighted theoretically. But that is not the point. Just as any predator stalking its prey relies on knowledge acquired from a study of signs, yet not every predator is a semiotician; so every semiotician owes his or her profession to the fact that someone, in fact, Augustine of Hippo, first introduced into intellectual culture the notion of sign in general, under which notion the particular investigations we call semiotics are brought together objectively in the conception of a unified subject matter of possible investigation. There are not only signs as tokens; there is also sign as type, the type defining and distinguishing those investigations properly called "semiotic" in contrast to "chemical", "astronomical", "biological", and so forth, even though we can also say, from the standpoint of semiotic consciousness, that every other subject matter physical or cultural necessarily involves and develops by semiotic means.

Sign itself, the general notion or type (the "general mode of being", Peirce liked to say) of which all particular signs are instances or tokens, then, is the first and foundational element of the semiotic heritage. For it is that presupposed notion which first makes the development of a doctrine of signs possible in the first place. It marks, as we may say, the initial awakening of semiotic consciousness; and it occurs more or less at the very beginning of the Latin Age in the history both of the formations that lead to modern Europe and of that part of intellectual culture traditionally called philosophy. Semiotic consciousness owes its initial awakening, if not its name, to the introduction of the general notion of sign in the work of Augustine. ${ }^{21}$

But what after Augustine? Does the Latin Age contribute nothing more to semiotic consciousness than its foundational and organizing notion of sign? As a matter of fact, Augustine's original and constitutive contribution in this regard risked in advance the disaster of nominalism, that infection of speculative thought which blinds the mind to the dependence in understanding of everything the senses yield upon general modes of being insensible as such, yet as independent or more independent of human whim as anything on the order of rocks or stars.

21 See Augustine i. 397-426 in particular. 
For it is not enough to propose the general notion of sign as a mode of being. The proposal needs to be theoretically justified as well. How is it possible for there to be such a thing as a general mode of being that transcends the division of objective being into what exists prior to and independently of cognition and what exists posterior to and dependently upon cognition or mind?

This question never occurs to Augustine. For him, as for the next seven centuries of Latin thinkers, the general idea of sign seems so intuitively valid that we find it employed throughout the theological and philosophical writings without the appearance of a second thought. Of course, the seven centuries in question are not exactly luminous with speculative developments within philosophy. In fact, they are precisely what first the renaissance humanists and many modern historians after them refer to derisively as "the dark ages", the centuries marked more by the collapse than by the rise of centers of serious learning. This was a function of the condition of civilization itself in the early indigenous Latin centuries. But by the time in the $11^{\text {th }}$ and $12^{\text {th }}$ centuries when we see the universities, that greatest of all the contributions to present civilization surviving from the polities of the Latin Age, begin to form at Paris and Bologna and then all across what will become Europe, spreading even to China by 1900, the "constantly alive, burning and inevitable problem",22 Augustine has bequeathed to Latin posterity makes its way to the fore. Signum: general mode of being or empty nominalism, flatus vocis?

The burning question bursts into flame at least as early as the writings of Aquinas (1225-1274) and Roger Bacon (c. 1214-1292). The first turn the controversy takes toward a generally theoretical development of Augustine's posit hanging in thin air (for what is to prevent the vocable signum from being a sound signifying nothing, like "phlogiston" or "aether" or "immutable crystalline spheres" any of the countless other words posited across the centuries which turn out to be names for confusions in thought that, when clarified, disappear) fastens not on the general notion itself but on the question of whether only a sensible object can function in the capacity of a sign, whether being a sensible material structure was rightly included in the general definition. For Augustine's posit had two aspects: the general notion of sign as verified in whatever makes present for awareness something besides itself, and a proposed definition that ties this functioning to impressions made upon sense. 
It was over the formulation of Augustine's definition of sign that the problem first broke into open flames. Beginning with Aquinas ${ }^{23}$ and Bacon, ${ }^{24}$ then developing after them in the writings of Duns Scotus (c. 1266-1308), William of Ockham (c. 1285-1349), Pierre d'Ailly (1350-1420), Dominic Soto (1495-1569), Pedro da Fonseca (1528-1599), the Conimbricenses (1606, 1607), Francisco Araújo (1580-1664), and culminating in the work of John Poinsot (15891644), this first aspect of the problem received an all but unanimous resolution among the Latins: not only sensible objects as sensible, but also those interpretive structures of the mind (called today "ideas and images" but in those times "species expressae") on the basis of which sensible objects are presented in experience as this or that kind of thing, fulfill the function essential to being a sign. A common terminology even evolved, after d'Ailly (or perhaps before, for this terminological point has not quite been pinned down as yet historically), to mark the point linguistically. Sensible objects as such which make present in cognition something besides themselves the Latins agreed to call "instrumental signs", while those interpretive structures of thought as such, those psychological states of the knower, as we would say, which serve to found the relations which make sensible objects present at their terminus as this or that kind of individual they called by contrast "formal signs". 25

But this agreement on terminology proved to be but a verbal agreement, which is perhaps why it has proved to have little enduring power beyond the time of those who forged it. In fact, the comity

\footnotetext{
23 Especially with Aquinas, for even though he never focused thematically on sign as a question of systematic pursuit, his work is so vast, and problems central to the eventual formation of such a systematically pursued theme recur tangentially to issues he does systematically pursue, that he leaves a trail of tantalizing suggestions to be pursued over the entire corpus of his writings: c. 1254-1256: the Commentary on the Sentences of Peter Lombard, Book IV, dist. 1, q. 1, quaestiunc. 2; c. 1256-1259: the Disputed Questions on Truth, q. 4. art. 1 ad 7, q. 9. art. 4 ad 4 and ad 5; c. 1269-1272: the Questions at Random, q. 4 art. 17; c. 1266-1273/4: the Summa theologiae III, q. 60 , art. 4 ad 1. Indeed just this trail is what Poinsot will follow in bringing to publication 358 years after Aquinas' death the first systematic demonstration of a being common to all signs as such, and hence the first demonstration (in contrast to posit) of the existence of a unified subject matter for semiotic inquiry. It will be exactly 353 more years before this effort of Poinsot will surface outside of the Latin language - such is the slow rhythm of semiotic development.

24 See esp. Bacon c. 1267.

25 The fullest historical discussion of this first phase of the later Latin development is presented in Meier-Oeser 1997: "Die Unterscheidung von signum formale — und signum instrumentale”, pp. 238-251.
} 
among the differing Latin schools on this verbal point served to mask a much deeper disagreement that became apparent to the cognoscenti as soon as the question of Augustine's defining formula was realized to involve the more profound problem of the very being proper to signs, of the type manifested in the tokens - of the being, that is to say, enabling signs, any and every sign as such, to function as a sign in the first place.

Augustine's original proposal of a general definition may have been too narrow, as all came to agree, but at least it had the merit of applying to particular things. Now Ockham and his followers increasingly distinguished themselves by insisting that only particular things are real. Ideas of the mind may not be sensible characteristics of individuals, but they are subjective characteristics of individuals no less than is the color of one's skin or the shape of one's nose. My idea is as much a part of my subjectivity as is my shape or size or color. Hence the nominalists could distinguish formal and instrumental signs as respectively inaccessible and accessible to direct sense perception without admitting that there is any type or general mode of being verified equally in the differing tokens or instances of sign. ${ }^{26}$ For be it a

26 This second and decisive aspect of the late Latin development of semiotic consciousness has so far not been discussed in the literature, and Meier-Oeser, in his work splendid as far as it goes, appallingly misapprehends this aspect of the problem. I can refer the reader only to Chapters 8-10 of my forthcoming book, Four Ages of Understanding (see the "promissory note" in Deely 1996a), which traces the complete history of philosophy from Thales to Eco in terms of the bearing that history has on the current and prospective development of semiotics as the positive essence of what can only be called (in philosophy at least, where "modernity" is defined by the epistemological paradigm according to which the human mind is capable of knowing only the products of its own operations) a postmodern development. The opening of the new historical epoch, in fact, may be dated specifically to May 14, 1867, when Peirce presented his "New List of Categories". For the list in question contrasts both with Aristotle's original list of c.360BC, by including specifically the objective products of mind as well as the knowable elements of physical nature, and also with Kant's list of 1781, by including specifically objective, i.e., directly and immediately known, elements of physical nature as well as phenomena owing their whole being to the mind's own operations.

For the creation, in Peirce's "New List", of an "intersection of nature and culture" (Sebeok 1975a; cf. also Sebeok 1979), set the problematic of the sign squarely beyond the modern quarrels between idealism and realism, in conformity exactly with the terms originally set by John Poinsot for beginning a systematic development of the doctrine of signs (1632: 117/24ff.): "the sign in general ... includes equally the natural and the social sign", that is to say, "even the signs which are mental artifacts". And if there is anything which philosophy cannot account for and remain within the constraints of the Descartes-Locke equation of ideas with the objects of direct experience, 
sound or mark, an idea or a feeling, the former as "instrumental" no less than the latter as "formal" remains a particular, not a general, mode of being. The mind in knowing may make comparisons among objects of which it is aware, and from these comparisons relations do indeed result. But the relations themselves, the relations as such, do not precede the knowing: they are constituted by it. Prior to the knowing, prior to the comparison and independent of it, there remain only the particulars, the subjectivities: that is all.

The Scotists and the Thomists accepted the terminology for distinguishing between signs whose foundation was and signs whose foundation was not directly sense-perceptible (instrumental vs. formal signs, respectively), but they also insisted, against the nominalists, on a more fundamental point: when a particular object or an idea is said to be a "sign", what makes the appellation true is not the particularity of the feature in question but the fact that it serves to ground a relation to something other than itself. This relation, not the individual characteristic upon which the relation is based, they insisted, is what constitutes the being proper to the sign as such. Thus the Latin authors eschewing nominalism insisted that not only was Augustine wrong to propose a definition tying signs to sense-perceptible objects as such, but that the reason why he was wrong was not merely that ideas as well as words and rocks serve as vehicles of signification. The reason is much more profound, namely, that the relations actually and properly constituting signs are always as such and in every case without exception knowable as such only to understanding in its distinction from the perception of sense - exactly what we assert today when we recognize that linguistic communication arises from a species-specifically distinct modeling system, and that it is this modeling system as such, ${ }^{27}$ not the linguistic communication exapted from its distinctive function, that constitutes "language" in the species-specifically human root sense - a capacity more obscurely designated (from a semiotic point of view) "intellect" among the Latins and "understanding" among the later moderns.

Here, unnoticed by any currently established historian of philosophy, the theoretical divide between the nominalists and their Latin opponents widens to a chasm. For the nominalists relations exist only as mind-dependent elements of awareness through and through, as

it is the possibility of a knowledge of structures of the physical environment according to a being proper to them.

27 See esp. Sebeok 1987. 
comparisons made in thought by the mind itself. They exist wholly within and function as no more than a distinguishing part of subjectivity itself actively cognizing - subjectivity: that total complex of characteristics and functions whereby one individual in nature exists unto itself as distinct from the rest of the universe. For those opposing nominalists in the matter of resolving the "burning and inevitable problem" bequeathed from Augustine, relations are as much a part of nature as are individuals, and in fact are a part of nature apart from which individuals could not so much as exist as distinct individuals. For while indeed in the Latin notion of "substance" there is embodied the affirmation of natural individuals, beings existing "in themselves and not in another as in a subject of existence", the nominalist interpretation of that notion (the only interpretation, it would appear, familiar to the classical authors from whose works sprang the distinctively modern mainstream of philosophy) is completely at loggerheads with the notion as we find it in Aquinas and Scotus or their followers among the Latins, or as we find the notion of substance before them in the Greek texts of Aristotle.

For the opponents of nominalism among the Latins, substance itself is a relative notion; for the individual, "absolute" insofar as its being is one, is yet only relatively distinct from the surrounding universe. The individual maintains its actual existence as relatively distinct only through and on the basis of an unremitting series of interactions which provenate and sustain a network of actual relations, relations mind-independent and physical and essential to the continuance of subjectivity even though not themselves subjective, which link the individual to what it itself is not but upon which it depends even in being what it is. So we find distinguished subjectivity and intersubjectivity: substance, as a relative notion of what exists in itself dependently upon other things besides itself (subjectivity), distinguished from intersubjectivity or rather suprasubjectivity, pure relations as such which actually link the individual to whatever it is that the individual depends upon in its existence in whatever way without being that other thing. Intersubjectivity in this pure sense thus characterizes the individual but does not reduce to the subjectivity of the individual. Individual characteristics are thus both subjective and intersubjective, and the actual existence of the individual as relatively distinct from and within its physical surroundings depends upon both types of characteristics. 
The nominalists denied that these intersubjective characteristics had any reality outside of thought, any reality over and above subjectivity itself. For over and above subjectivity, the being of particulars, some of which happen to include cognition as part of their particularity, there is nothing at all "in the nature of things". All relations, Ockham asserted, and all the nominalists after him agreed (including Hobbes, Locke, Berkeley, and Hume; Descartes, Spinoza, Leibniz and $\mathrm{Kant}^{28}$ ), are constituted only in and by thought itself whenever and only insofar as the mind makes comparisons between objects and aspects of objects.

Comparisons the mind makes do indeed give rise to relations within thought, countered the later followers of Scotus and Aquinas. But what makes these relations unique is not the fact that thought forms them so much as the fact that they are suprasubjective without needing to be in fact intersubjective. Indeed, thought is able to form comparative relations only because the understanding has already recognized in actu exercito intersubjectivity as a feature of the reality of the physical world, the order of things in the experience of the physical aspects of our surroundings. On the basis of our experience of such features the mind can go on to make comparisons of its own. These further comparisons, like relations in nature, will be "between" objects as linking one to the other, but with this difference: relations between individuals in the physical environment cannot exist except as intersubjective, whereas relations fashioned by thought, always interobjective, yet may or may not be intersubjective in fact, inasmuch as one or the other term of such a relation either may not exist at all, or may not exist in the manner that thought presents it to exist. I may be mistaken about who my father is, even though there is no question that in fact I have a father. That is the whole and only difference between minddependent and mind-independent relations insofar as they are relations, but a difference that reveals a distinctive feature of pure relations as such that will prove crucial for understanding how signs are

\footnotetext{
28 Such a spectrum of authors agreeing on so basic a point is worth documenting, and the first one to do so in a brief and systematic compass, I believe, was Weinberg 1965 - although Peirce himself, as early as 1898 (CP 4.1), to cite a specific mention of a point that runs throughout his writings, had full taken note that not only is every modern philosopher from Descartes to Hegel a nominalist, but further that "as soon as you have once mounted the vantage-ground of the logic of relatives ... you find that you command the whole citadel of nominalism, which must thereupon fall almost without another blow."
} 
possible: ${ }^{29}$ while every pure relation exists as such over and above whatever subjectivity the relation depends upon in order to actually exist here and now, only some relations are in fact intersubjective. Therefore the feature essential to and constitutive of the purely relative as such is not intersubjectivity in fact but suprasubjectivity.

If that is so, and every sign consists in a relation as such, then every sign as such serves to link an individual to something that is other than itself, whether or not this other signified actually exists in any physical sense as a subjectivity in its own right. The implications of this point are not only enormous, they are decisive for semiotics. The point enables us to see, in the first place, how signs can be used indifferently to lie, to blunder, or to express some truth: the situation depends upon factors wholly external to the sign relation as such, just as my being or not being an uncle is quite independent of anything I do. But perhaps the most interesting theoretical implication of this last point developed among the Latins, tentatively with the Conimbricenses and Araújo, definitively with Poinsot and, after him and independently, with Peirce, is the implication that the relations in which signs consist according to their proper being as signs differ from physical relations in nature in having of necessity (or "in principle") three terms united rather than only two. In other words, it suffices for intersubjective instances of relation to be dyadic, whereas the suprasubjective instantiations of relations as signs (which realize the indifference in the nature of relation to provenance from physical being as such) must always be triadic. A car can hit a tree only if there is a tree there to be hit; but a sign can warn a bridge is out whether or not the bridge is out, or, for that matter, whether or not there is even a bridge there at all where the sign "leads us to believe" there is a defective one!

Semiotic consciousness, thus, first arose in the time of Augustine, but its principal development as a theoretical theme did not occur until much later, beginning with Aquinas and Roger Bacon in the $13^{\text {th }}$ century and continuing thereafter right down to the time of Galileo and Descartes. This main period of theoretical development occurred in two phases, both of which have been identified only in the most recent times and both of which have only begun to be explored in depth.

The first stage occurs between Aquinas and Ockham, or perhaps rather d'Ailly, when it comes clearly to be recognized that the being proper to signs need not be directly perceptible to sense, a recognition

29 Perhaps it is not to much to say that grasping the semiotic bearing of this point is what constitutes the uniqueness of Poinsot's Tractatus of 1632. 
that culminates in the linguistic marker of the "formal/instrumental sign" distinction. The second stage occurs between Soto and Poinsot, when it comes clearly to be recognized that the being proper to signs not only need not but cannot be directly perceived by sense, for the reason that this being is constituted not by any subjective characteristic as such upon which a relation happens to depend existentially (such as the shape of an object perceived or the contour of a sound heard) but by the very relation itself which, as suprasubjective - as over and above its sense-perceptible occasion of existing (its "foundation" in the Latin sense) - is never sense-perceptible and need not even be intersubjective. It follows from this that sign relations, that is to say, the relations in which the being proper to signs as such consists (or, simply, in which signs most formally and properly speaking consist), must also be triadic and never merely dyadic; and this remains true even when the sign happens to relate actually existing physical subjectivities, for actuality in that sense depends upon factors wholly extrinsic to the sign-relation as such.

It further follows that signs are never mere individual things but exist only insofar as individual beings are involved with things other than themselves, and this with "others" both actually existing and only possibly existing or once having existed (as in the case of dead parents) or only thought mistakenly to exist or have existed. The sign, it turns out, is not merely an object linking another object in thought but that upon which every object depends in order to be in thought at all, whether truly or falsely. And all of this depends on the doctrine of relation which the Latins inherited from Aristotle's discussion of categories of physical being. But the Latins expanded upon Aristotle's terse text enormously, ${ }^{30}$ especially under the pressure of seeking to come to terms with "the burning and inevitable problem" (or rather nest of problems) which Augustine, in his ignorance of Greek, had so casually handed them with his naive, innocent proposal of sign as a genus to which culture no less than nature contributes species.

\footnotetext{
30 This can be seen most readily in their subsumption of Aristotle's categorial relation, the relatio praedicamentalis seu realis, together with the thought-constituted relation, relatio rationis, under the more general rubric of relatio secundum esse, together with their setting of this general mode of being in contrast with the order of subjectivity tout court subsumed under the rubric of relatio transcendentalis seu secundum dici, which latter expression conveyed the requirement both for discourse and for physical existence that substances (subjectivities or "absolute" beings) be always in interactions and pure relations with their surroundings either to be or to be understood. See esp. the "Second Preamble" of Poinsot's Tractatus.
} 
In this way we find that, as it belongs to the cultural heritage of the species anthropos, semiotic consciousness is an originally and indigenously Latin development, first made possible thematically at the outset of the Latin Age by Augustine's naive posit, but first reduced systematically to its theoretical ground in the being proper to relation by John Poinsot's Treatise on Signs, a work brought to print as the Latin Age is nearing its end, and thereafter lost for more than three centuries in the language that almost became its tomb.

How recent is this discovery of the crucial role of the Latin past and how far we have to go to achieve something like a general appreciation of that crucial role may be garnered obliquely from the fact that even as the $20^{\text {th }}$ century ends distinguished figures in the nascent field of semiotics who name their ancestry appear routinely ignorant of more than half of the Latin names brought up in this discussion, including most glaringly that of John Poinsot, who stands easily without peer in uncovering the foundations in being itself of the semiotic consciousness which Augustine may have introduced thematically but which proves on sufficient further investigation to be the consciousness most distinctive of the human animal. It is not as "rational" that the human being finds its distinctive flourishing nearly so much as it is as signifying. We may even go so far as to say that semiotics as an essentially postmodern development carries with it the implication of a new definition of the human being. Even as Descartes introduced modernity by replacing the ancient definition of human being as animal rationale with the modern formula, res cogitans, so the advent of semiotics at once transcends modernity in the direction of the past and surpasses it in the direction of a future in which the "thinking thing" becomes rather once again an animal, the animal semeioticum. I turn to my second terminological point, my second "essence freighted with being".

\section{Where is the Latin in the English word "semiotics"?}

Here I will not repeat even in substance the several times ${ }^{31}$, inspired by the seminal essay of Romeo, ${ }^{32}$ that I have explored in detail

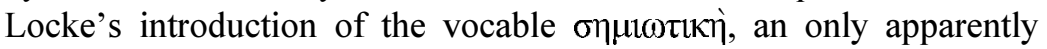
Greek word, misspelled at that, as it turns out, into the concluding

31 Deely 1977, 1978, 1982, 1985, 1986, 1990a, 1993, 1994a: 109-143, 1994b.

32 Romeo 1977. 
English paragraphs (so brief is his final chapter ${ }^{33}$ ) of his Essay concerning Human Understanding of 1690, which propounds in its body an epistemological theory that is anything but hospitable to or compatible with this alternative development he concludes by suggesting $^{34}$ - namely, the "way of signs", as I think it should be called.

Let us cut to the chase, and reach our main conclusions.

We have seen that if we take the English word "sign" and ask where it comes from, the answer is that it comes from Augustine of Hippo, the first thinker of record to forge a general notion of sign as a genus (we might even say "genius") to which natural and cultural phenomena alike are species.

But "semiotics" as an English word is more problematic. Surely its derivation is Greek, as at least learned common sense can divine from its very alphabetic formation. But here common sense, as is usual with even with learned common wisdom, relies on a secret covenant with ignorance. What investigation of the matter shows is that the linguistic formation in question comes about from a kind of bastard Greek coinage actually made by the Englishman John Locke when he proposes

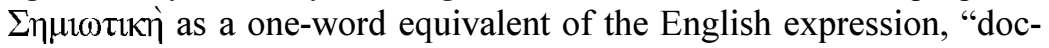
trine of signs" - itself an expression not merely redolent of but exactly translating, almost to a point of proving an exception to Hill's dictum on the non-existence of perfect synonyms, the older and wellestablished Latin formula central to the work of Poinsot and others: doctrina signorum. Locke's term may have come indirectly, as Romeo persuasively urges, from a Greek medical dictionary. Be that as it may, it remains that the term as it appears in Locke is malformed. By the applicable requirements of Greek grammar, it should have had an epsilon separating the mu from the iota, which it did not. Nor can this malformation be dismissed as a printer's error; for, in every subsequent edition of the Essay prepared by Locke prior to his being overtaken by the boundary of time and made a definitively past author, the original malformation is meticulously maintained. ${ }^{35}$

Now it is curious that "semiotics" is not a straight transliteration of Locke's Greek malformation. What is a straight transliteration of

33 The whole of Locke's chapter from the original edition of his Essay is photographically reproduced in Deely 1994a: 112 .

34 I would refer the reader to the Allen - Deely exchange in The American Journal of Semiotics 11(3/4).

35 I have actually verified this through combined holdings of the Library of Congress and the libraries of the Smithsonian Institution, both in Washington, DC. 
the Greek malformation Locke introduced, however, is the Latin term "semiotica", which no Latin author ever used. So the term, a Greek malformation in Locke's Essay, is in effect a neologism in Latin transliteration. But the term means in English "the doctrine of signs", according to the only definition Locke provided in his original introduction of and comment upon the would-be Greek term.

The reason that this detour through the nonexistent Latin transliteration of Locke's Greek malformation is interesting is because "semiotica" as Latin neologism would be a neuter plural name that could only be translated into English as "semiotics". Professional linguists have been careful to point out that there is in English a class of "-ics" words which do not conform to the usual rule that an English noun is made plural by adding an "s" to its ending. ${ }^{36}$ By this reckoning, "semiotics" is not the plural form of "semiotic". Nonetheless, "semiotics" is the direct English transliteration of the Latin "semiotica", which in turn is the direct transliteration of the Greek malformation Locke introduced into the closing chapter of his Essay, and would be a true English plural if taken from the Latin.

So a Latin, rather than a Greek, background proves etymologically decisive for sign and semiotics alike as contemporary notions, despite Locke's conscious choice of the Greek root (sem-) for the notion of "natural sign" (semeion) in his one-word summation or name (semiotike) for the doctrine of signs.

Of course, the Greek philosophical contribution to what would eventually take form in contemporary culture as an explicit attempt to develop the doctrine of signs can hardly be underestimated, particularly in Aristotle's doctrine of categories - for example, with his sharp development of the contrast between subjective being in the doctrine of substance (what Poinsot clarified long-standing Latin usage by terming transcendental relation, ${ }^{37}$ which is not really relation at all but subjective being itself viewed in terms of its existential and ontological dependencies upon the surroundings), and suprasubjective being in the doctrine of relation (which Poinsot followed Aquinas in terming ontological relation ${ }^{38}$ ). But it remains that it is first in the late

\footnotetext{
36 "At least a part of the confusion which learners experience in handling the -ics words ... is caused by the fact that no dictionary makes clear that the final $-s$ in these words, no matter what its origin, is not identical with the familiar plural morpheme of nouns which happens to be homonymous with it" (Hill 1948).

37 Actually relatio transcendentalis seu relatio secundum dici, since in fact we know of no case where Poinsot spoke or wrote a word of English.

38 Again actually: relatio secundum esse.
} 
$4^{\text {th }}$ century Latin of Augustine that the general notion of sign appears, and that it is first in the early $17^{\text {th }}$ century Latin of Poinsot that this general notion is decisively fully vindicated as more than a nominalism. Contemporaneously, the Latin Age itself recedes into the shadows of times past as modern philosophers with their nominalistic doctrine of ideas as the objects of direct experience take control of European intellectual development in philosophy.

\section{Comments in closing}

By the time Charles Peirce passed from the status of future, that is, not yet living, to the status of present contributor to philosophical discussion, the richness of the Latin notion of signum, its origin, development, and vindication over the 1200 or so years of the Latin Age, had passed into oblivion, forgotten to all present contributors to the discussion of philosophy. Peirce in this matter, fortunately for us all, proved not to be a typical modern. He did not contemn the past of philosophy, in particular its Latin past. He undertook instead to explore it. ${ }^{39}$ And, though his explorations did not reach as far as the work of Poinsot, they did bring him as far as Poinsot's principal teachers and immediate predecessors in the matter of the doctrine of signs, Thomas Aquinas, Duns Scotus, and the Conimbricenses.

As a result, Peirce was able to recover the Latin notion of signum very nearly at the point where the Latins had left it, that is to say, at the point where it had been realized and definitively explained that signs strictly speaking are not their sensible or psychological vehicles, but that this vehicle, loosely called a "sign" (especially in the case where it is a sensible object), is but the subjective foundation or ground (the vehicle, we might say) for an irreducibly triadic relation which, in its proper being, is not subjective but suprasubjective in linking its subject term to a terminus or object signified as represented to some observer or interpretant, prospective or actual in its subjective being; and which, as a relation, is indifferent to passing back and forth between psychological and material vehicles of conveyance. Thus, while both the sign vehicle and the observer when actual are subjective beings, the sign itself is always and irreducibly suprasubjective.

39 The matter has been documented in Beuchot and Deely 1995. And I suggest that one of the most telling results of his Latin forays were his singular "ethics of terminology": see Peirce 1903, Deely 1998a. 
And the "object signified" or significate of the sign is itself always and irreducibly sustained as the direct terminus of a triadic relation regardless of whether it has any subjective being at all as an immediate part of its objective being, its "objectivity", or status as signified.

If the most important development for the immediate future of philosophy (and perhaps for intellectual culture as a whole) is to be, as I believe, the realization of the centrality of the doctrine of signs to the understanding of being and experience for human animals, then Peirce's recovery of the notion of signum from the Latins may be said to have marked the beginning of new age in philosophy. By overcoming the forgottenness of signum, the veritable Zeichensvergessenheit of modernity (as including Heidegger in this particular), Peirce also destroyed the common foundation upon which the mainstream modern philosophers (from Descartes and Locke to Kant in the classical phase, continuing with analytic philosophers and phenomenologists in our own day) had constantly built. There are some today who embrace modern philosophy's culminating doctrine that only the mind's own constructions are properly said to be known, ones who have yet tried to coin and appropriate the phrase "postmodern" to advertise their stance. But the vain appropriation cannot conceal the stipulation which guarantees that these would-be postmoderns are nothing more than surviving remnants of a dying age, the last of the moderns, in fact, the "ultramoderns". The future, in philosophy and in intellectual culture more broadly conceived, belongs rather to semiotics, the clearest positive marker we have of the frontier which makes modernity be to the future of philosophy what Latinity was to philosophy's future in the time of Galileo and Descartes - though this time we will hardly be able to repeat Descartes mistake of counting history as nothing, as the joint work of Williams and Pencak ${ }^{40}$ has perhaps best shown.

\section{References}

Aquinas, Thomas i. 1252-1273. S. Thomae Aquinatis Opera Omnia ut sunt in indice thomistico, ed. Roberto Busa. Stuttgart-Bad Cannstatt: FrommannHolzboog, 1980, in septem volumina: 1. In quattuor libros Sententiarum;

2. Summa contra Gentiles, Autographi Deleta, Summa Theologiae; 3. Quaestiones Disputatae, Quaestiones Quodlibetales, Opuscula; 4. Com-

40 See Williams and Pencak 1991; and Williams 1984, 1985, 1985a, 1985b, 1990, 1990a. 
mentaria in Aristotelem et alios; 5. Commentaria in Scripturas; 6. Reportationes, Opuscula dubiae authenticitatis; 7. Aliorum Medii Aevi Auctorum Scripta 61.

- c. 1254/6a. In quattuor libros sententiarum Petri Lombardi, in Busa ed. vol. 1.

— c. 1256/9. Quaestiones Disputatae de Veritate, in Busa ed. vol. 3, 1-186.

— c. 1269/72. Quaestiones Quodlibetales, Quodlibet 4, in Busa ed. 3, 438501.

- i. 1271/3. Summa theologiae tertia pars, in Busa ed. 2, 768-926.

Allen, Barry 1994. Is Locke's Semiotic Inconsistent? The American Journal of Semiotics 11(3/4): 23-31.

Augustine of Hippo 397. Aureli Augustini Confessionum Libri Tredecim, Latin text in O'Donnell 1992: I, 1-205; English text Confessions Books IXIII, trans. F. J. Sheed, introduced by Peter Brown. Indianapolis: Hackett Publishing Co.

- i. 397-426. De doctrina christiana libri quattuor (Four Books On Christian Doctrine). In: Tomus Tertius Pars Prior, 13-151; also Patrologiae Cursus Completus, ed. J. P. Migne, Series Latina (PL), Volume 34, cols. 15-122.

Bacon, Roger c. 1267. De Signis. In: Fredborg, Nielsen, and Pinborg(eds.), Traditio. Volume XXXIV. New York: Fordham University Press, 1978, 81-136.

Beuchot, Mauricio 1980. La doctrina tomista clásica sobre el signo: Domingo de Soto, Francisco de Araújo y Juan de Santo Tomás. Critica 12(36) (México, diciembre), 39-60.

- 1983. Lógica y lenguaje en Juan de Sto. Tomás. Diánoia 17.

- 1986. Signo y Lenguaje en San Agustín. Diánoia (anuario de filosofia) 32: $13-26$.

- 1987. Metafísica. La Ontología Aristotélico-Tomista de Francisco de Araśjo. México City: Universidad Nacional Autónoma de México.

- 1993. La percepción sensible en Santo Tomás de Aquino. In: Benítez, Laura; Robles, José A. (eds.), Percepción: Colores (= La Filosofía y Sus Problemas; México City: Universidad Nacional Autónoma, Instituto de Investigaciones Filosóficas), 11-29.

- 1994. Intentionality in John Poinsot. $A C P Q$ 68(3) (Summer 1994): 279296.

- 1995. Algunas Teorías del Signo en la Escolastica Iberica Post-Medieval, selección de textos, introducción y traducción. Maracaibo y Caracas, Venezuela: Universidad del Zulia y Universidad Católica Andrés.

- 1998. Bañez, Domingo (1528-1604), entry. Routledge Encyclopedia of Philosophy, ed. in 10 volumes by Edward Craig. London: Routledge, 1, 647-649.

Beuchot, Mauricio, and Deely, John 1995. Common Sources for the Semiotic of Charles Peirce and John Poinsot. Review of Metaphysics 48(3) (March): 539-566. 
Deely, John 1971. The Tradition via Heidegger. An essay on the meaning of being in the philosophy of Martin Heidegger. The Hague: Martinus Nijhoff.

- 1977. 'Semiotic' as the Doctrine of Signs. Ars Semeiotica 1(3): 41-68.

- 1978. What's in a Name. Semiotica 22(1/2): 151-181 (essay review of Sebeok 1976).

- 1982. Introducing Semiotic: Its History and Doctrine. Bloomington: Indiana University Press; trans. by Vivina de Campos Figueiredo as Introdução à Semiótica: historia e doutrina. Lisbon, Portugal: Fundação Calouste Gulbenkian, 1995.

- 1982a. On the Notion "Doctrine of Signs", Appendix I - Deely 1982: 127-130.

- 1985.Semiotic and the Liberal Arts. The New Scholasticism 59(3) (Summer): 296-322. The "second epsilon" mentioned in this work is a blunder, for the "first epsilon" in the Greek "semeiotic" is not an epsilon but an

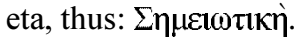

- 1986.John Locke's Place in the History of Semiotic Inquiry. In: Deely, John; Lanham, Jonathan Evans (eds.), Semiotics 1986. MD: University Press of America, 406-418.

- 1986a. Semiotic in the Thought of Jacques Maritain. Recherche Sémiotique/Semiotic Inquiry 6(2): 1-30.

- 1986b. Doctrine, terminological entry for the Encyclopedic Dictionary of Semiotics, ed. Thomas A. Sebeok et al. Berlin: Mouton de Gruyter, Tome I, 214.

- 1989. The Grand Vision, presented on September 8 at the September 5-10 Charles Sanders Peirce Sesquicentennial International Congress at Harvard University, forthcoming in Colapietro and Olshewsky 1994. This essay was first published in the Transactions of the Charles S. Peirce Society 30( 2) (Spring 1994): 371-400, but, inexplicably, after the submission of corrected proofs, the journal repaged the whole and introduced such extreme errors as to make the text unreadable at some points. The correct version has appeared as Chapter 7 of Deely 1994a: 183-200.

- 1990. Basics of Semiotics. Bloomington: Indiana University Press.

- 1990a. Logic Within Semiotics. In: Bernard, Jeff; Deely, John; Prewitt, Terry; Voigt, Vilmos and Withalm, Gloria (eds.), Symbolicity. MD: University Press of America, 1993, 77-86; Symbolicity is bound together with Semiotics 1990, ed. Karen Haworth, John Deely, and Terry Prewitt as a single volume.

- 1991. Semiotics and Biosemiotics: Are Sign-Science and Life-Science Coextensive? In: Sebeok, Thomas A.; Umiker-Sebeok, Jean (eds.), Biosemiotics. The Semiotic Web 1991. Berlin: Mouton de Gruyter, 1992, 4575. Since revised as Chapter 6 How Do Signs Work? - Deely 1994a: 151-182.

- 1993. Locke's Proposal for Semiotics and the Scholastic Doctrine of Species. The Modern Schoolman 70(3) (March): 165-188. 
- 1994. The Human Use of Signs; or Elements of Anthroposemiosis. Lanham, MD: Rowman \& Littlefield.

- 1994a. New Beginnings. Early Modern Philosophy and Postmodern Thought. Toronto, Canada: University of Toronto Press.

- 1994b. Why Investigate the Common Sources of Charles Peirce and John Poinsot? In: Spinks, C. W; Deely, John (eds.), Semiotics 1994. New York: Peter Lang Publishing, 1995, 34-50.

- 1994c. Locke's Philosophy vs. Locke's Proposal for Semiotic. The American Journal of Semiotics 11(3/4): 33-37.

- 1995. Ferdinand de Saussure and Semiotics. In: Tasca, Norma (ed.), Ensaios em Homagem a Thomas A. Sebeok, quadruple Special Issue of Cruzeiro Semiótico. Porto, Portugal: Fundação Eng. António de Almeida, 7585.

- 1996a. Los Fundamentos de la Semiótica, trans. José Luis Caivano. Mexico City, Mexico: Universidad Iberoamericana. An expanded text of Deely 1990.

- 1996a. The Four Ages of Understanding between Ancient Physics and Postmodern Semiotics. In: Spinks, C. W; Deely, J. N (eds.), Semiotics. New York: Peter Lang Publishing, Inc., 1997, 229-240.

- 1997. How Is the Universe Perfused with Signs? In: Spinks, C. W.; Deely, J. N. (eds.), Semiotics. New York: Peter Lang Publishing, Inc., 1998, 389-394.

- 1997a. Quid Sit Postmodernismus? Postmodernism and Christian Philosophy (a Proceedings of the American Maritain Association; Washington, D C: Catholic University of America Press), 68-96.

- 1998. Physiosemiosis and Semiotic. In: Spinks, C. W.; Deely, J. N. (eds.), Semiotics. New York: Peter Lang Publishing, Inc., 1999.

- 1998a. The Ethics of Terminology. In: Colapetrio, Vincent (ed.), $A C P Q$ Special Issue on Peirce, 72(2): 197-243.

- 2000. What Distinguishes Human Understanding? South Bend, St. Augustine's Press.

- 2000a. Four Ages of Understanding. The first postmodern history of philosophy from ancient times to the turn of the $21^{\text {st }}$ century. Toronto, Canada: University of Toronto Press.

Deely, John N.; Williams, Brooke and Kruse, E. Felicia (eds.). 1986. Frontiers in Semiotics. Bloomington: Indiana University Press. Preface titled "Pars Pro Toto", viii-xvii; Description of Contributions, xviii-xxii.

Doyle, John P. 1984. The Conimbricenses on the Relations Involved in Signs. In: Deely, John (ed.), Semiotics. Proceedings of the Ninth Annual Meeting of the Semiotic Society of America; Lanham, MD: University Press of America, 1985, 567-576.

- 1994. Poinsot on the Knowability of Beings of Reason. American Catholic Philosophical Quarterly 58(3) (Summer 1994): 337-362. 
Eco, Umberto; Lambertini, Roberto; Marmo, Costantino and Tabarroni Andrea 1986. Latratus Canis or: The Dog's Barking — Deely, Williams, and Kruse 1986: 63-73.

Fisch, Max H. 1978. Philodemus and Semiosis (1879-1883), Section 5 of the essay Peirce's General Theory of Signs. In: Sebeok, Thomas A. (ed.), Sight, Sound, and Sense. Bloomington: Indiana University Press, 31-70.

Heidegger, Martin 1947. Brief über den Humanismus. Platons Lehre von der Wahrheit. Bern: Francke Verlag. A separate and independent edition of the so-called Letter on Humanism was published in 1949 by Klosterman of Frankfurt.

Hill, Archibald A. 1948. The Use of Dictionaries in Language Teaching. Language Learning 1: 9-13.

- 1958. Introduction to Linguistic Structures. From sound to sentence in English. New York: Harcourt, Brace.

Manetti, Giovanni 1993. Theories of the Sign in Classical Antiquity. Bloomington: Indiana University Press, trans. by Christine Richardson of Le teorie del segno nell'antichità classica, Milan: Bompiani, 1987.

Maritain, Jacques Note: the writings of Maritain are so diverse and have appeared in so many translations with so many modifications that it needs to be noted that in the thirteen years spanning 1983 and 1995 the Cercle d'Etudes Jacques et Raïssa Maritain (in the persons of Jean-Marie Allion, Maurice Hany, Dominique and René Mougel, Michel Nurdin, and Heinz R. Schmitz) established the definitive text of all the writings and brought them to publication in 15 volumes entitled Jacques et Raïssa Maritain. Oeuvres Complčtes. Editions Universitaires Fribourg Suisse et Editions Saint-Paul Paris, 1983-1995. In citing Maritain from this set, I will abbreviated it to OC (for Oeuvres Complètes) followed by volume number in Roman numerals and pages in Arabic numbers.

- 1937-1938. Sign and Symbol, trans. Mary Morris for the Journal of the Warburg Institute I: 1-11.

- 1938. Signe et Symbole. Revue Thomiste 44 (April): 299-330.

- 1943. Sign and Symbol, English trans. by H. L. Binsse of 1938 entry above q.v., but with footnotes separated from the text proper at the end of the volume. Redeeming the Time. London: Geoffrey Bles, text 191-224, Latin notes 268-276.

- 1956. Le Langage et la Theorie du Signe, Annexe au Chapitre II of Quatre Essais sur l'Esprit dans sa Condition Charnelle (nouvelle edition revue et augmentée; Paris: Alsatia), 113-124. This Chapitre II is the text of the entry for 1938 above.

- 1957. Language and the Theory of Sign. In: Anschen Ruth Anda (ed.), Language: An Enquiry into Its Meaning and Function. New York: Harper and Brothers, 86-101. Text of 1956 entry preceding, but with several paragraphs added near the beginning to make the essay self-contained when published apart from the 1938 main essay text. These added paragraphs summarize the section The Theory of the Sign in 1943: 191-195, 
to which the extensive Latin notes drawn from Poinsot's 1632 treatise on signs are appended. The 1957 English text is being reprinted with the full Poinsot references to 1632a restored, and with some glosses added from the 1943 English trans. of the 1938 main entry, in Deely, Kruse, and Williams, eds., 1986: 49-60.

- 1966. Le Paysan de la Garonne, in OC 12: 663-1035.

Meier-Oeser, Stephan 1995. Entry Semiotik, Semiologie. In: Ritter, Joachim and Gründer, Karlfried (eds.), Historisches Wörterbuch der Philosophie. Basel: Schwabe, Band 9, cols. 601-608.

- 1997. Die Spur des Zeichens. Das Zeichen und seine Funktion in der Philosohie des Mittelalters und der frühen Neuzeit. Berlin: Walter de Gruyter.

Peirce, Charles Sanders. Note: all eight volumes of The Collected Papers of Charles Sanders Peirce, Vols. I-VI ed. Charles Hartshorne and Paul Weiss (Cambridge, MA: Harvard University Press, 1931-1935), Vols. VII-VIII ed. Arthur W. Burks (same publisher, 1958), are now available in electronic form in an edition prepared by Charlottesville, VA: Intelex Corporation, 1994.

- 1898 Lecture series, Detached Ideas on Vitally Important Topics (the passage in CP 4.1 is from Lecture 2).

- 1903. The Ethics of Terminology from A Syllabus of Certain Topics of Logic. Boston: Alfred Mudge \& Son, 10-14; reprinted in CP 2.219-2.226 continuing 1.202 (Burks p. 295).

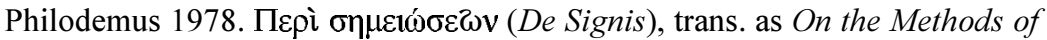
Inference in the ed. of Phillip Howard De Lacy and Estelle Allen De Lacy, rev. with the collaboration of Marcello Gigante, Francesco Longo Auricchio, and Adele Tepedino Guerra. Naples: Bibliopolis, Greek text 27-87, English 91-131.

Poinsot, John 1632. Tractatus de Signis. The Semiotic of John Poinsot, critical edition presented and translated by John Deely with the assistance of Ralph Austin Powell (first independent edition; Berkeley, CA: University of California Press, 1985). Available also in electronic form (Charlottesville, VA: Intelex Corp., 1992).

Romeo, Luigi 1976. Heraclitus and the Foundations of Semiotics. Versus 15(5) (dicembre): 73-90. Reprinted without the brief section on philological sources (75-79) in Deely, Williams, \& Kruse 1986: 224-234.

- 1977. The Derivation of 'Semiotics' through the History of the Discipline. Semiosis 6(2): 37-49.

- 1979. Pedro da Fonseca in Renaissance Semiotics: A Segmental History of Footnotes. Ars Semeiotica 2(2): $190 \mathrm{ff}$.

Saussure, Ferdinand de 1916. Cours de linguistique général (Paris: Payot). Lectures delivered at the University of Geneva i. 1906-1911 and posthumously published from auditors' notes by Charles Bally and Albert Sechehaye with the collaboration of Albert Riedlinger. 
Sebeok, Thomas A. 1971. 'Semiotic' and Its Congeners. In: Jazayery, Mohammed Ali; Polomé, Edgar C.; Winter Werner (eds.), Linguistic and Literary Studies in Honor of Archibald Hill, I: General and Theoretical Linguistics. Lisse, Netherlands: Peter de Ridder Press, 283-295; reprinted in Sebeok 1985: 47-58, and in Deely, Williams and Kruse 1986: 255-263.

- 1975. The Semiotic Web: A Chronicle of Prejudices. Bulletin of Literary Semiotics 2: 1-63; reprinted "with essential corrections and additions" Sebeok 1976: 149-188, to which reprint page numbers in the present monograph are keyed.

- 1975a. Zoosemiotics: At the Intersection of Nature and Culture. In: Sebeok, T.A. (ed.), The Tell-Tale Sign. Lisse, the Netherlands: Peter de Ridder Press, 85-95.

- 1976. Contributions to the Doctrine of Signs (= Sources in Semiotics IV; Lanham, MD: University Press of America, 1985 reprint with a new Preface by Brooke Williams of the original book as published by Indiana University, Bloomington, and The Peter De Ridder Press, Lisse).

- 1979. Semiosis in Nature and Cultur, as reprinted. The Sign \& Its Masters (= Sources in Semiotics VIII; Lanham, MD: University Press of America, 1989), 3-26.

- 1984. Vital Signs, Presidential Address delivered October 12 to the ninth Annual Meeting of the Semiotic Society of America, Bloomington, Indiana, October 11-14; subsequently printed in The American Journal of Semiotics 3(3): 1-27, and reprinted in Sebeok 1986: 59-79.

- 1984b, June 3. The Evolution of Communication and the Origin of Language - lecture in the June 1-3 ISISSS '84 Colloquium on Phylogeny and Ontogeny of Communication Systems. Published under the title Communication, Language, and Speech. Evolutionary Considerations Sebeok 1986: 10-16.

- 1984c. Symptom, Chapter 10 of New Directions in Linguistics and Semiotics, ed. James E. Copeland. Houston: Rice University Studies, 212-230.

- 1985. Contributions to the Doctrine of Signs (= Sources in Semiotics IV; reprint of 1976 original with an extended Preface by Brooke Williams, Challenging Signs at the Crossroads [Williams 1985], evaluating the book in light of major reviews; Lanham, MD: University Press of America).

- 1987. Language: How Primary a Modeling System. In: Deely, John (ed.), Semiotics. Lanham, MD: University Press of America, 1988, 15-27.

- 1989. The Sign \& Its Masters (= Sources in Semiotics VIII; Lanham, MD: University Press of America). Corrected reprint with a new author's Preface and editor's Introduction of the University of Texas Press 1979 original imprint.

- 1996. Galen in Medical Semiotics. Interdisciplinary Journal for Germanic Linguistics and Semiotic Analysis 1(1) (Spring): 89-111.

Santaella-Braga, Lúcia. 1991. John Poinsot's Doctrine of Signs: The Recovery of a Missing Link. The Journal of Speculative Philosophy, New Series, 5(2): 151-159. 
- 1992. A Assinatura das Coisas. Rio de Janeiro: Imago Editora.

- 1994. The Way to Postmodernity, preface - Deely 1994a: xv-xvi

Tasca, Norma (ed.) 1995. Ensaios em Homagem a Thomas A. Sebeok, quadruple Special Issue of Cruzeiro Semiótico. Porto, Portugal: Fundação Eng. António de Almeida.

Weinberg, Julius Rudolph 1965. Abstraction, Relation, and Induction: three essays in the history of thought. Madison, WI: University of Wisconsin Press.

Williams, Brooke 1984. Preface to Logic, Philosophy, and History (A. F. Russell 1984).

- 1985. Challenging Signs at the Crossroads — prefatory essay to Sebeok 1985: xv-xlii.

- 1985a. History and Semiotic. Toronto Semiotic Circle Monograph, No. 4; Victoria University of the University of Toronto.

- 1985b. What Has History To Do with Semiotics. Semiotica 54.3/4: 267333.

- 1990. Uma década de debates: História e Semiótica nos annos 80", Face 3(1) (janeiro/junho): 11-28.

- 1990a. Re-posing the Objectivity Question. In: Haworth, Karen; Deely, John; Prewitt Terry (eds.), Semiotics. Lanham, MD: University Press of America, 1991, 87-95

— 1991. History and Semiotics in the 1990s. Semiotica 83 (3/4): 385-417.

Williams, Brooke, and Pencak, William (eds.) 1991. Special Issue: History and Semiotics, Semiotica 83 (3/4).

\section{Семиотика как переоткрытие бессознательного культуры в постмодернистскую эпоху}

В данной статье мы исследуем терминологию семиотики с целью выявить исторические слои человеческого опыта и понимания, способствовавшие превращению учения о знаках в одно из течений современной мысли. Исходя в основном из хайдегтеровской концепции языка как эвристической гипотезы, мы анализируем термин "семиотика" и выявляем, что Бл. Августин впервые придал латинскому слову "signum" тот смысл, который сделал возможным появление общего учения о знаках, а понятие знака как общего модуса бытия, конкретно верифицируемого и в природе, и в культуре в процессе структурирования человеческого опыта, было обосновано лишь в позднейшей латинской традиции в соответствии с объяснением возможности такого модуса бытия. Далее мы рассматриваем причины того, почему уже в современную эпоху Чарлз Пирс вер- 
нулся к латинской традиции обоснования понятия знака, в основном завершенной в работах Пуансо. Оставаясь в рамках той же самой традиции, мы пытаемся понять, почему термин "семиотика" возник в качестве, так сказать, логического наименования глобального интереса к знакам.

\section{Semiootika kui kultuuri mitteteadvuse uuestiavastamine postmodernistlikul ajajärgul}

Artiklis vaadeldakse semiootilist terminoloogiat eesmärgiga tuua välja inimkogemuse ja arusaamise ajaloolised kihid, mis tegid võimalikuks märgidoktriini tekkimise tänapäevases mõistes. Lähtudes peamiselt Heideggeri arusaamast keelest kui heuristilisest hüpoteesist, uuritakse nimetust semiootika ja jõutakse järeldusele, et vaid tänu Augustinuse poolt kasutatavale ladinakeelsele terminile signum sai võimalikuks üldise märgidoktriini tekkimine. Just ladina kultuuri hilisperioodil kerkib esmakordselt esile märgi kui looduses ja kultuuris olemise üldmooduse inimkonna kogemuse struktureerimisprotsessi käigus verifitseeritav mõiste. Ladinakeelne tõestusliin oli lõpuni viidud Poinsot' töödes ja selle tänapäevane taastagasitulek sai teoks läbi Peirce'i. Jäädes selle traditsiooni raamesse, vaadeldakse termini semiootika esilekerkimist loogilise nimetusena globaalsele märgihuvile. 